\title{
Detection of Staphylococcus aureus and Methicillin Resistant Staphylococcus aureus (MRSA) from Bovine Raw Milk by PCR
}

\author{
Sonuwara Begum ${ }^{1}$, G. Suganya ${ }^{2}$ and M. Sekar ${ }^{3}$ \\ Department of Veterinary Public Health and Epidemiology, \\ Madras Veterinary College, Chennai-600007 \\ *Corresponding author
}

\section{Keywords}

Staphylococcus aureus, Methicillinresistant Staphylococcus aureus (MRSA), Polymerase chain reaction, Conventional

Article Info

Accepted: 24 June 2018 Available Online: 10 July 2018

\section{A B S T R A C T}

Staphylococcus aureus and Methicillin-resistant Staphylococcus aureus (MRSA) has been considered to be a major cause of healthcare infections worldwide and poses a major threat to public health. It is also one of the main etiological agents which is responsible for clinical and subclinical mastitis in dairy herds. This study was designed to investigate the occurrence of S. aureus and Methicillin resistant Staphylococcus aureus (MRSA) from bovine raw milk by Polymerase chain reaction (PCR) targeting thermonuclease (nuc) and mecA gene. A total of 115 bovine raw milk samples were collected and screened for the presence of $S$. aureus and MRSA. The samples were processed by standard conventional procedures for isolation of the $S$. aureus organism. Conventional culture method which include, Brain heart infusion broth with $10 \%$ sodium chloride followed by direct plating on Baird-Parker agar (BP) at $37^{\circ} \mathrm{C}$ for $24-48$ hours. Molecular characterization of the isolates was done by PCR targeting thermonuclease (nuc) gene for $S$. aureus and for Methicillin Resistant Staphylococcus aureus (mecA) gene was used. Out of 115 milk samples 52/115 $(45.22 \%)$ samples were found positive for $S$. aureus by conventional culture method. DNA was extracted from all the presumptive positive isolates. PCR targeting nuc gene for $S$. aureus and mecA gene for MRSA was carried out and the results showed that out of 48/52 (92.31\%) for nuc gene and 39/52 (75\%) for mecA gene were positive. This study showed that the prevalence of $S$. aureus and MRSA in bovine milk can play a role in zoonotic transmission, and PCR can be used as one of the rapidly and highly sensitive tests for detection and classification of $S$. aureus and MRSA by targeting nuc and mecA gene.

\section{Introduction}

Staphylococci is the major cause of both nosocomial and community-acquired infections (Diederen and Kluytmans, 2006) and out of all the Staphylococcus species the most important is the $S$. aureus. It is a ubiquitous Gram-positive microorganism as well as an important opportunistic pathogen in human and also the main etiological agent of clinical and subclinical mastitis in dairy herds (Gilbert et al., 2006). Mastitis is one of the major causes of economic losses in dairy industry worldwide. Its presence in raw milk 
is a major concern for the safety and the quality of traditionally dairy products (Elbes $e t$ al., 2006).

The emergence of multi-drug resistance in Staphylococcus aureus bacteria has become a major healthcare problem. Today greater than $95 \%$ of all $S$. aureus isolates possess resistance to penicillin and $40-60 \%$ of clinical isolates in the United States of America and the United Kingdom express methicillin resistance (Levy and Marshall, 2004; Neu, 1992).

Methicillin-resistant Staphylococcus aureus (MRSA) has been recognised as major cause of healthcare-associated infections worldwide. MRSA is a pathogen emerging in hospitals as well as in community and livestock. MRSA strains appear to have been transferred from health care settings into the community and have emerged as particularly associated with community-associated infections in humans (Scientific Report of EFSA and ECDC, 2015).

In recent years, MRSA has been identified as an emerging pathogen in livestock and companion animals, as well as some other farm animal species (Antoci et al., 2013). Resistance to methicillin is conferred by the mecA gene which encodes a modified penicillin-binding protein (PBP2a or PBP2), that has low affinity for almost all $\beta$-lactam antibiotics (penicillins, cephalosporins, carbapenems).

The mecA locus is a highly conserved gene that encodes PBP2a in resistant strains but is absent from susceptible ones making it a useful molecular marker of $\beta$-lactam resistance (Pinho et al., 2001). Also, MRSA strains are often resistant to antimicrobials other than $\beta$-lactams of which many members are widely used in both human and veterinary medicine (Lowy, 2003; Pinho et al., 2001). Thus the detection of the mecA gene using polymerase chain reaction (PCR) can be used to identify MRSA.

The aim of this study was to isolate and molecular characterization of $S$. aureus and Methicillin resistant Staphylococcus aureus (MRSA) from bovine raw milk by Polymerase chain reaction (PCR) targeting thermonuclease (nuc) and mecA gene.

\section{Materials and Methods}

\section{Ethical approval}

Milk samples were collected as per standard method without any harm to the animals so approval from Institutional Animal Ethics Committee to carry out this study is not required.

\section{Sample collection}

A total of 115 raw milk samples were randomly collected from cows brought to Madras Veterinary College (MVC) Teaching Hospital, Chennai. The milk samples were collected aseptically in sterilized screwcork tubes and transported in an icebox to laboratory of the Department of Veterinary Public Health and Epidemiology, MVC, Chennai for further processing and microbiological analysis.

\section{Isolation of Staphylococcus species}

Isolation of Staphylococcus spp. from milk samples was done by enriching into sterile Brain heart infusion broth supplemented with $10 \%$ sodium chloride and incubated at $37^{\circ} \mathrm{C}$ for overnight and selective plating was done by transferring loopful of inoculum on BairdParker (BP) agar medium supplemented with (5\% Egg yolk tellurite and $3.5 \%$ potassium tellurite) and incubated at $37^{\circ} \mathrm{C}$ for $24-48$ hours. 


\section{Bacterial identification based on cultural and morphological characteristics}

\section{Cultural characteristics}

Appearance of circular, smooth, moist, jet gray black to jet black colonies surrounded by a clear halo zone were considered to be presumptive for S. aureus (Fig. 1).

\section{Morphological characteristics}

Microscopic examination of the smear slide stained with Gram's stain revealed Gram positive, spherical cells arranged in irregular clusters resembling to bunch of grapes (Fig. 2).

\section{Polymerase Chain Reaction (PCR) for detection of nuc and mecA gene}

\section{DNA extraction}

Presumptive Staphylococcus aureus isolates were used for extraction of DNA by Alkanine lysis Polyethylene glycol (AL-PEG) method as outlined by Chomczynski and Rymaszewski (2006). DNA was extracted by taking a loopful of presumptive colonies and dissolved in $100 \mu \mathrm{l}$ of distilled water and 500 $\mu \mathrm{l}$ of AL-PEG reagent which constitute of $(60 \mathrm{~g}$ PEG $+0.93 \mathrm{ml} 2 \mathrm{M} \mathrm{KOH}+39 \mathrm{ml}$ water $)$ for $100 \mathrm{ml}$ AL-PEG reagent) was added and incubated in water bath at $60^{\circ} \mathrm{C}$ for 10 minutes. Supernatant was collected in separate eppendorf and from this 2-3 $\mu$ l of supernatant was used as a template for PCR.

\section{Primers used for PCR}

Molecular characterization of the isolates was done by targeting the thermonuclease (nис) gene for $S$. aureus and Methicillin resistant Staphylococcus aureus (MRSA) by using $m e c A$ gene. Details of the primers and cycling condition are given in Table 1 and 2.

\section{PCR reaction}

PCR was performed in a $25 \mu \mathrm{l}$ reaction mixture which includes $12.5 \mu \mathrm{l}$ master mix (Ampliqon), $10 \mathrm{pM}$ concentration of each primer and $2.5 \mu \mathrm{l}$ of DNA template and remaining volume was adjusted using nuclease free water.

\section{Electrophoresis and gel documentation}

PCR products (amplicon) were subjected to gel electrophoresis $(1.2 \%$ agarose gel with $0.8 \mu \mathrm{g} / \mathrm{ml}$ ethidium bromide) at $100 \mathrm{~V}$ for 30 min was performed. Gels were visualized under UV transilluminator and the results were documented using gel documentation system (Biorad).

\section{Results and Discussion}

S. aureus causes a variety of diseases in human and animals. Infections vary from a mild skin infection to severe pneumonia and septicemia (Lowy et al., 1998). Staphylococcus aureus is associated with subclinical mastitis in dairy cattle and may be present in milk and other dairy products (Capurro et al., 2010). The emergence of multi-drug resistance in Staphylococcus aureus bacteria has become a major healthcare problem in recent years. MRSA is a significant public health concern given its ability to contaminate food of animal origin and to colonize and infect humans and animals (Petinaki and Spiliopoulou, 2012). In this study a total of 115 bovine milk samples was collected randomly out of which 52/115 (45.22\%) samples were found positive for $S$. aureus by conventional culture method. DNA was extracted from all the presumptive positive isolates for $S$. aureus by culture. PCR targeting nuc gene for $S$. aureus and mecA gene for MRSA was carried out and the results showed that out of $48 / 52(92.31 \%)$ for nuс gene and 39/52 (75\%) for mec A gene were positive (Fig. 3 and 4). 
Table.1 Details of the primers

\begin{tabular}{|c|c|c|c|}
\hline Target & Primer Sequence 5',-3', & Amplicon size (bp) & Reference \\
\hline$n u c-\mathbf{F}$ & GTGCTGGCATATGTATCGCAATTGT & \multirow[t]{2}{*}{181} & \multirow[t]{2}{*}{ Hedge, 2013} \\
\hline nuc-R & TACGCCCTTATCTGTTTGTGATGC & & \\
\hline mecA-F & GAAATGACTGAACGTCCGATAA & \multirow[t]{2}{*}{310} & \multirow[t]{2}{*}{$\begin{array}{l}\text { Kobayashi et al., } \\
1994\end{array}$} \\
\hline mecA-R & CCAATTCCACATTGTTTCGGTCTAA & & \\
\hline
\end{tabular}

Table.2 Primers cycling conditions

\begin{tabular}{|l|l|l|l|l|l|}
\hline Sl.No & Cycling condition & $\begin{array}{l}\text { nuc gene } \\
\text { Temperature and }\end{array}$ & $\begin{array}{l}\text { mecA gene } \\
\text { Time }\end{array}$ & $\begin{array}{l}\text { Temperature and } \\
\text { Time }\end{array}$ & Cycles \\
\hline $\mathbf{1 .}$ & Initial Denaturation & $94^{\circ} \mathrm{C} 5$ minutes & 1 & $94^{\circ} \mathrm{C} 5$ minutes & 1 \\
\hline $\mathbf{2 .}$ & Denaturation & $94^{\circ} \mathrm{C} 30$ seconds & & $94^{\circ} \mathrm{C} 30$ seconds & \\
\hline $\mathbf{3}$ & Annealing & $54^{\circ} \mathrm{C} 30$ seconds & 30 & $50^{\circ} \mathrm{C} 40$ seconds & 25 \\
\hline $\mathbf{4}$ & Extension & $72^{\circ} \mathrm{C} 30$ seconds & & $72^{\circ} \mathrm{C} 1$ minute & \\
\hline $\mathbf{5}$ & Final extension & $72^{\circ} \mathrm{C} 10$ minutes & 1 & $72^{\circ} \mathrm{C} 5$ minutes & 1 \\
\hline
\end{tabular}

Fig.1 Characteristic colonies in BP agar medium (circular, smooth, moist, gray black to jet black colonies, surrounded by a clear halo zone were considered to be presumptive for $S$. aureus zone

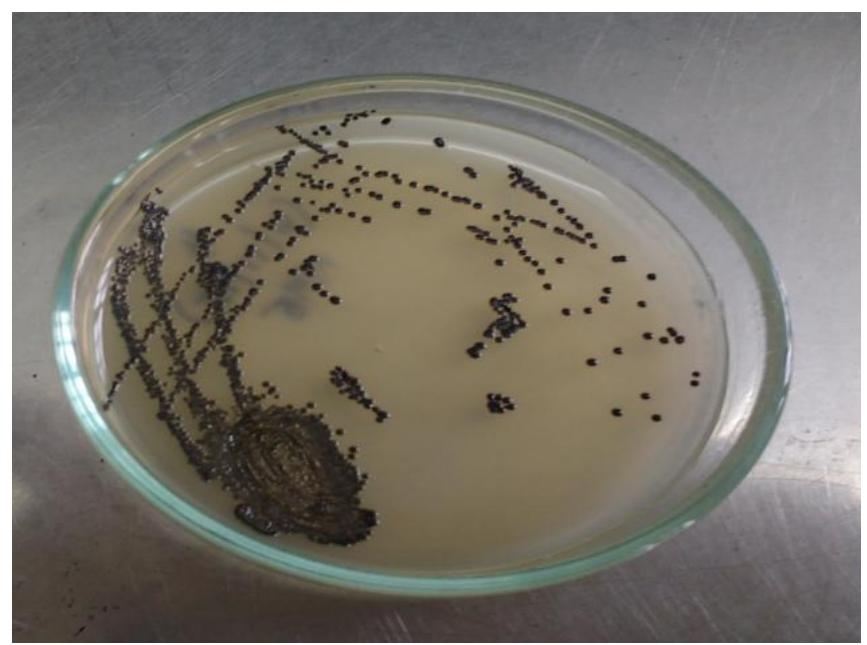


Fig.2 Gram's staining showing spherical cells arranged in irregular clusters resembling to bunch of grapes

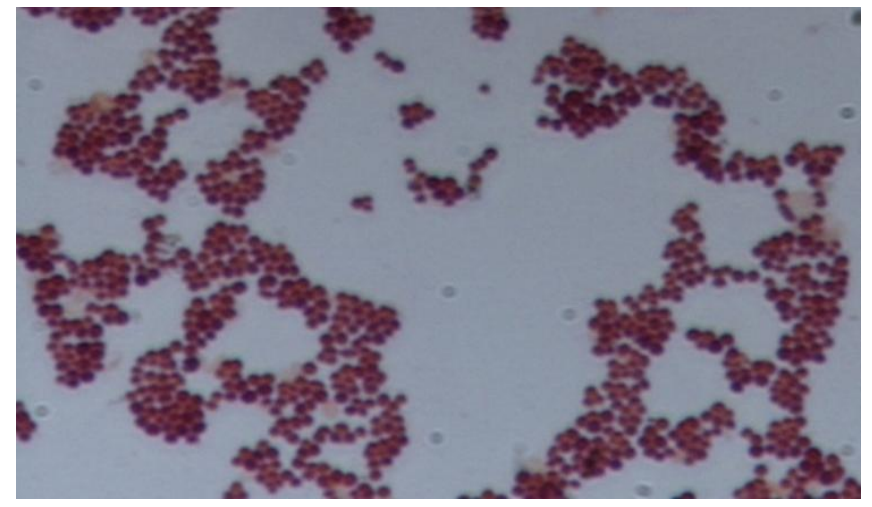

Fig.3 Agarose gel electrophoresis of PCR product amplified from nuc gene (181 bp)

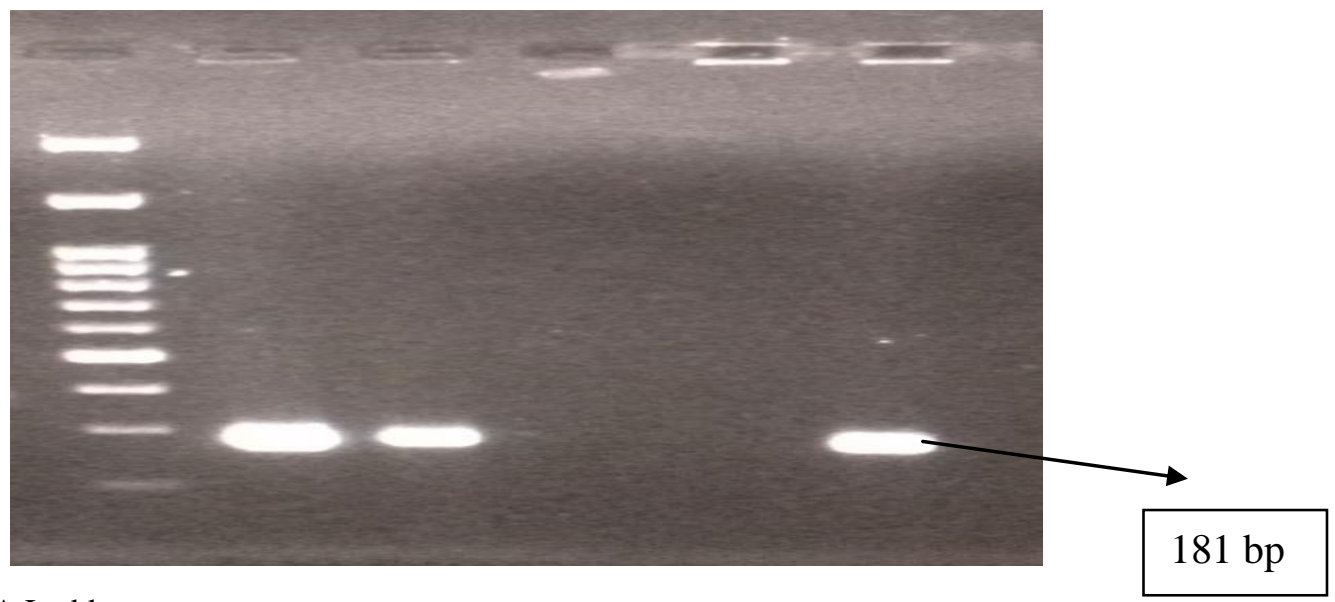

Lane 1 - 100 bp DNA Ladder

Lane 2 - Positive control

Lane 3,6-positive samples

Lane 4, 5- negative samples

Fig.4 Agarose gel electrophoresis of PCR product amplified from mecA gene (310 bp)

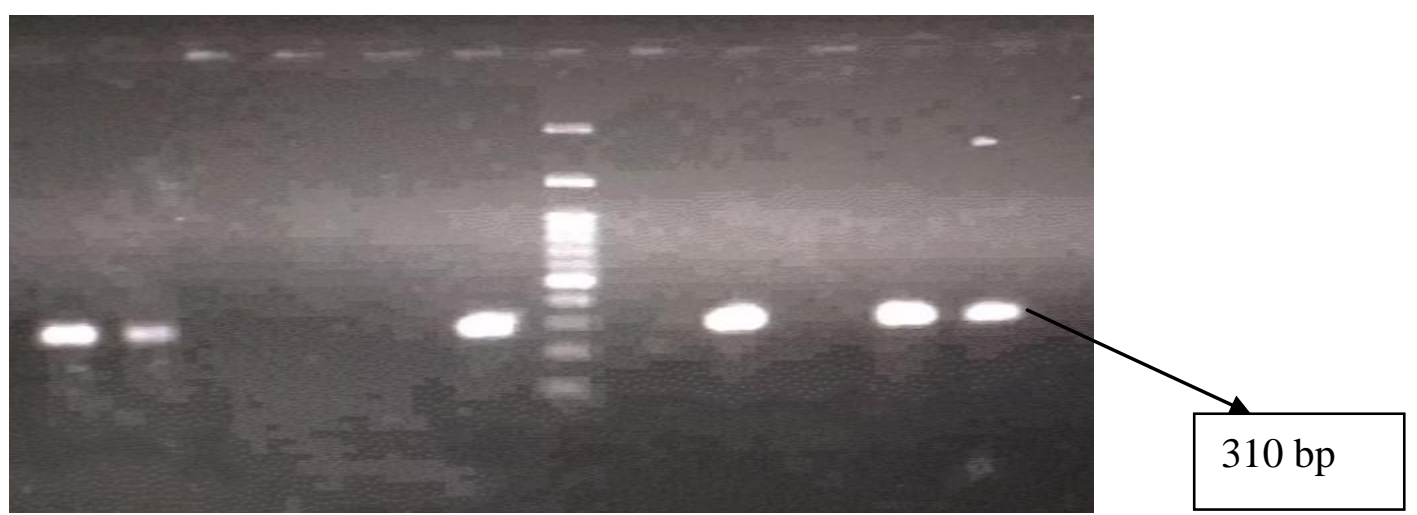

Lane 7 - 100bp DNA ladder

Lane $6-m e c A$ positive control

Lane 3,4,5,8,10- Negative samples

Lane 1, 2, 9,11,12 - Positive samples 
The primary objective of this study was to isolate and identify $S$. aureus and MRSA from bovine raw milk. In this study the overall presence of $S$. aureus by conventional culture method was $45.22 \%$ (52/115). Further confirmation was done by doing PCR targeting nuc gene for $\mathrm{S}$. aureus and mecA gene for MRSA and the results showed that $92.31 \%(48 / 52)$ and $75 \%$ (39/52) samples were positive for $S$. aureus and MRSA.

Isolation rates of $S$. aureus observed in our study is consistent with the findings of other studies such as $53.3 \%$ by Gundogan et al., (2005), 57.3\% by Ertas et al., (2010) and $52.4 \%$ by Gucukoglu et al., (2012). In another study (Orges et al., 2008) observed S. aureus in $67 \%$ of isolates from raw milk. Worldwide several studies suggest that $S$. aureus isolation rates in milk can vary from $(13.5 \%)$ to (64.7\%) (Umathi et al., 2008; Nakal and Kaliwal, 2010). In Morocco, Bendahou et al., (2008) studied 27 samples and found $40 \%$ of the milk samples were containing $S$. aureus, Lingathurai and Vellathurai, (2010) $61.7 \%$ of the raw milk samples were found positive out of 60 samples studied

The $n u c$ gene is widely employed as the target gene for specific detection of $S$. aureus (Wilson et al., 1991; Kim et al., 2001; Ramesh et al., 2002). Akindolire et al., (2015) also used PCR targeting nuc gene for identification of $S$. aureus and the proportion of $S$. aureus was higher $(75 \%)$ in raw milk than in pasteurised milk (29\%).

Our results are in accordance with the results of various authors who has also reported the presence of MRSA by using PCR based mecA gene amplification which confirmed more than $99 \%$ of MRSA isolates (Hata et al., 2010). Chandrasekaran et al., (2014) reported $49.36 \%$ samples positive for $S$. aureus of which $10.34 \%$ were MRSA from clinical mastitis milk samples. Riva et al., (2015) found that the prevalence of $S$. aureus was
$9.1 \%$ in raw milk and the $20 \%$ were MRSA. Out of the total 160 milk samples, $36(22.5 \%)$ samples yielded $S$. aureus by using nuc gene and 23SrRNA gene. Out of the total 36 confirmed $S$. aureus isolates, 6 (16.6\%) isolates were confirmed to be MRSA when subjected to PCR amplification using specific primers for mecA gene (Hamid et al., 2017).

Variation in the prevalence percentage of $S$. aureus in comparison to other workers might be due to sample size, antibiotic use in animal husbandry and hygiene practices among the dairy cows. The source of acquisition of MRSA may be due to contact with human or animal carriers. MRSA infected cattle acts as a reservoir and later transmit the infections to other animals and humans (Spoor et al., 2013).

MRSA colonization in cattle may be an occupational risk to the people in close contact with MRSA infected cattle viz. veterinarians, farmers, milkers and people working at slaughterhouses (Paterson et al., 2012; Juhasz- Kaszanyitzky et al., 2007). High incidence of $S$. aureus is indicative of poor hygienic measures during production, handling and distribution, (Zakary et al., 2011).

The presence of S.aureus and MRSA in milk is a matter of concern and it needs strict farm management practices as well as proper sanitary procedures such as storage, handling and transportation plays major factor in $S$. aureus contamination. As well as proper heat treatment followed by the refrigeration can minimize the chance of contamination with $S$. aureus and monitoring of food-producing animals and improving hygiene in food practices in order to limit the spread of the microorganism and reduce the microbiological risk to minimum.

In conclusion, irrational use of antibiotics in the treatment of human diseases and non- 
therapeutic use of antibiotics in animals have played a significant role in the emergence of resistant clones due to selection pressure. Such resistance may pose a great impact on public health if animal associated strains enter into the community and health care settings.

This study was intended for isolation and identification of $S$. aureus and MRSA from bovine raw milk. The data obtained from this study showed the prevalence of $S$. aureus and MRSA from milk and PCR was a very useful tool in investigating this by targeting nuc and $m e c A$ gene.

Further studies should be conducted to monitor the presence and evolution of these pathogens. Strict regulations on the use of antibiotics in human medicine as well as in animal food production, strengthening surveillance and screening of animal population are required for effective infection control programme to limit the spread of drug resistant clones of $S$. aureus.

\section{Authors' contributions}

SB and MS designed the study. Laboratory work was done by SB and GS. SB and GS prepared the manuscript and analyzed the data. SB and GS done collection of sample and isolation. All authors read and approved the final manuscript.

\section{Acknowledgments}

The authors wish to acknowledge the Faculty of Department of Veterinary Public Health and Epidemiology, Madras Veterinary College, Chennai (India) for providing the necessary facility to carry out the research.

\section{Competing interests}

The authors declare that they have no competing interests.

\section{References}

Akindolire Muyiwa Ajoke, Babalola Olubukola Oluranti, Ateba Collins Njie. 2015. Detection of Antibiotic Resistant Staphylococcus aureus from Milk: A Public Health Implication. Int. J. Environ. Res. Public Health. 12: 10254-10275.

Antoci, E., Pinzone, M.R., Nunnari, G., Stefani, S., Cacopardo, B. 2013. Prevalence and molecular characteristics of methicillin-resistant Staphylococcus aureus (MRSA) among subjects working on bovine dairy farms. Infez. Med. 21: 125-129.

Bendahou, A., Lebbadi, M., Ennanei, L., Essadqui, F.Z., Abdin, M. 2008. Characterization of Staphylococcus species isolation from raw milk and milk products (iIben and jben) in North Marocco. Journal of Infection in Developing Countries. 2: 218-225.

Capurro, A., Aspán, A., Unnerstad, H.E., Waller, K.P., Artursson, K. 2010. Identification of potential sources of Staphylococcus aureus in herds with mastitis problems. Journal of Dairy Science. 93: 180-191.

Chandrasekaran, D., Venkatesan, P., Tirumurugaan, K.G., Nambi, A.P., Thirunavukkarasu, P.S., Kumanan, K., Vairamuthu, S. 2014. A study on Methicillin resistant Staphylococcus aureus mastitis in dairy cows. Journal of Applied and Natural Science. 6 (2): 356-361.

Diederen, B.M., Kluytmans, J.A. 2006. The emergence of infections with community associated methicillin resistant Staphylococcus aureus. J Infect. 52(3):157-68.

Elbes, C., Alomar, J., Chougui, N., Martin, J. F. and Montei, M. C. (2006).Staphylococcus aureus growth and entertoxin production during the 
manufacture of uncooked,semi hard cheese from cow's raw milk. J. Food Prot. 69: 2161- 2167.

Ertas, N., Gonulalan, Z., Yildirim, Y., and Kum, E. 2010. Detection of Staphylococcus aureus enterotoxins in sheep cheese and dairy desserts by multiplex PCR technique. Int. J. Food Microbiol. 142: 74-77.

Gilbert, F., Fromageau, B., Gelineau A andPoutrel, M. 2006. Differentiation of bovine staohyloccus aureus isolates by use of poylmorphic tandem repeat typing. Vet. Microbiol. 117: 297-303.

Gücükoğlu, A., Kevenk, T. O., Uyanik, T., Çadirci, Ö., Terzi, G., and Alişarli, M. 2012. Detection of enterotoxigenic Staphylococcus aureus in raw milk and dairy products by multiplex PCR. J. Food Sci. 77: M620-M623.

Gundogan, N., Citak, S., Yucel, N., and Devren, A. 2005 A note on the incidence and antibiotic resistance of Staphylococcus aureus isolated from meat and chicken samples. Meat Sci. 69: 807-810.

Hamid, S., Bhat, M.A., Mir, I.A., Taku, A., Badroo, G.A., Nazki, S., Malik, A. 2017. Phenotypic and genotypic characterization of methicillinresistant Staphylococcus aureus from bovine mastitis Veterinary World. 10(3): 363-367.

Hata, E., Kobayashi, H., Nakajima, H., Shimizu, Y., Eguchi, M. 2010. Epidemiological analysis of Staphylococcus aureus isolated from cows and the environment of a dairy farm in Japan. The Journal of Veterinary Medical Science. 72(5): 647-652.

Juhasz-Kaszanyitzky, E., Janosi, S., and Somogy, P. 2007. MRSA transmission between cows and humans. Emerg Infect Dis. 13: 630-632.

Kim, C.H., Khan, M., Morin, D.E., Hurley,
W.L., Tripathy, D.N., Kehrli, M.J., Oluoch, O.A. and Kakoma, I. 2001. Optimization of the PCR for detection of Staphylococcus aureus nuc gene in bovine milk. Journal of Dairy Science. 84: 74-83.

Levy, S.B., Marshall, B.M. 2004. Antibacterial resistance worldwide: causes, challenges and responses. Nat Med. 10(12): 122-129.

Lingathurai, S. and Vellathurai, P. 2010. Bacteriological quality and safety of raw cow milk in Madurai, South India. Webmed Central Microbiology. 1: 110.

Lowy, F.D. 2003. Antimicrobial resistance: the example of Staphylococcus aureus. J. Clin. Invest.111: 12651273.

Lowy, F.D.,, Zinkawa, K., Omoe, S.,, Aasbakk, K., Macland A. 1998. Staphylococcus aureus infection. The New England Journal of Medicine. 339: 520-532.

Nakal, C.G. and Kaliwal, B.B. 2010. Prevalence and Antibiotic Susceptibility of Staphylococcus aureus from Bovine Mastitis. Vet World, 3: 65-67.

Neu, H.C., 1992. The crisis in antibiotic resistance. Science. 257 (5073): 10641073.

Orges, M.F., Nassu, R.T., Pereira, J.L., de Andrade, A.P.C. and Kuaye, A.Y. 2008. Contamination profile for staphylococci and its enterotoxins and monitorization of the conditions of hygiene in a 'coalho' cheese production line. Recebido para publicação 23.05.07.

Paterson, G.K., Larsen, J., Harrison, E.M., Larsen, A.R., Morgan, F.J., Peacock, S.J., Parkhill, J., Zadoks, R.N., and Holmes, M.A. 2012. First detection of livestock-associated meticillinresistant Staphylococcus aureus 
CC398 in bulk tank milk in the United Kingdom. Euro Surveill. 17(50): 20337.

Petinaki, E., Spiliopoulou, L. 2012. Methicillin-resistant Staphylococcus aureus among companion and foodchain animals: impact of human contacts. Clin. Microbiol. Infect. 18: 626-634.

Pinho, M.G., Filipe, S.R., De Lencastre, H., and Tomasz, A. 2001. Complementation of the essential peptidoglycan transpeptidase function of penicillin-binding protein 2 (PBP2) by the drug resistance protein PBP2A in Staphylococcus aureus. J. Bacteriol. 183: 6525-6531.

Ramesh, A., Padmapriya, B.P., Chandrashekar, A. and Varadaraj, M.C. 2002 Application of a convenient DNA extraction method and multiplex PCR for the direct detection of Staphylococcus aureus and Yersinia enterocolitica in milk samples. Molecular and Cellular Probes. 16: 307-314.

Riva, A., Borghi, E., Cirasola, D., Colmegna, S., Borgo, F., Amato, E., Pontello, M.M., Morace, G. 2015. MethicillinResistant Staphylococcus aureus in raw milk: prevalence, SCCmec typing, enterotoxin characterization, and antimicrobial resistance patterns. J. Food. Prot. 78: 1142-1146.

Scientific Report of EFSA and ECDC, 2015.
EU Summary Report on antimicrobial resistance in zoonotic and indicator bacteria from humans, animals and food in 2013. EFSA J. 13, 4036.

Spoor, L.E., McAdam, P.R., Weinert, L.A., Rambaut, A., Hasman, H., Aarestrup, F.M., Kearns, A.M.,. Larsen, A.R., Skov, R.L., and Fitzgerald, J.R. 2013. Livestock origin for a human pandemic clone of communityassociated methicillin resistant Staphylococcus aureus. mBio. 4(4): 00356-13.

Umathi, B.R., Veeregowda, B.M. and Amitha, R.G. 2008. Prevalence and Antibiogram Profile of Bacterial Isolates from Clinical Bovine Mastitis. Vet World, 8: 237-238.

Wilson, I.G., Cooper, J.E., and Gilmour, A. 1991 Detection of enterotoxigenic Staphylococcus aureus in dried skimmed milk: use of the polymerase chain reaction for amplification and detection of staphylococcal enterotoxin genes ent $B$ and ent $C 1$ and the thermonuclease gene nuc. Applied and Environmental Microbiology. 57: $1793-1798$.

Zakary, E., Marionette, M., Nassif, Z., Mohammed, G.M.O. 2011. Detection of Staphylococcus aureus in Bovine milk and its Product by Real Time PCR Assay. Global Journal of Biotechnology \& Biochemistry. 6: $171-177$

\section{How to cite this article:}

Sonuwara Begum, G. Suganya and Sekar, M. 2018. Detection of Staphylococcus aureus and Methicillin Resistant Staphylococcus aureus (MRSA) from Bovine Raw Milk by PCR. Int.J.Curr.Microbiol.App.Sci. 7(07): 3419-3427. doi: https://doi.org/10.20546/ijcmas.2018.707.397 